\title{
Retrospektivna analiza pojavnosti poremetnja ritma kod bolesnika sa zatajenjem srca na kardiološkom odjelu OB-a Dubrovnik
}

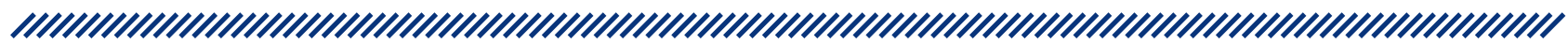

1 Vedrana Iveta

2 Anita Miljas

3 Mara Županić

1 Dom zdravlja Dubrovnik, Dubrovnik, Hrvatska

2 Opća bolnica Dubrovnik, Dubrovnik, Hrvatska

3 Zdravstveno Veleučilište, Zagreb, Hrvatska

\section{Sažetak}

Srčano zatajivanje jest skup simptoma i znakova koji nastaju zbog nesposobnosti srca kao mišićne crpke u omogućavanju dostatne perfuzije tkiva i organa, kako bi se zadovoljile njihove metaboličke potrebe. To je smrtonosna i onesposobljavajuća bolest koja spada u jedan od najvećih javnozdravstvenih problema suvremene civilizacije.

CILJ ISTRAŽIVANJA: Utvrditi pojavnost i vrstu aritmija u bolesnika sa zatajivanjem srčane funkcije.

ISPITANICI I POSTUPCI: Provedena je retrospektivna presječna studija. $U$ ispitivanje su uključeni hospitalizirani bolesnici s dijagnozom srčanog zatajenja nakon postavljanja kliničkog nalaza u koronarnoj jedinici Opće bolnice Dubrovnik u razdoblju od 1. siječnja 2015. do 31. prosinca 2016. Podaci su prikupljeni i obrađeni na temelju uvida u povijesti bolesti i drugu dostupnu medicinsku dokumentaciju.

REZULTATI: U istraživanju je sudjelovalo 96 ispitanika, od toga je $45(46,8 \%)$ muškaraca i $51(53,2 \%)$ žena $\left(\chi^{2}\right.$ test $\left.=0,258 ; d f=1 ; P<0,611\right)$. Srednja životna dob muškaraca bila je $72,0[17,0]$ godina, a žena $78,0[10,0]$ $(P<0,001)$. Od ukupnog broja ispitanika sa zatajivanjem srca s očuvanom istisnom frakcijom (HF-PEF) udio muškaraca bio je $33,3 \%$, a žena $66,7 \%$, dok je u skupini ispitanika sa zatajivanjem srca s reduciranom istisnom frakcijom (HF-REF) broj muškaraca iznosio 31 (57,4 \%), a žena $42,5 \%(P=0,019)$. Ispitanici s HF-PEF-om statistički su značajno stariji od ispitanika $S$ HF-REF-om $(P<0,001)$. Ispitanici s HF-PEF-om imaju statistički značajno veće srednje vrijednosti sistoličkog $(P=0,005)$ i dijastoličkog tlaka $(P<0,05)$. Najučestalija vrsta aritmije u ispitanika bila je fibrilacija atrija, potvrđena kod 46,8 \% ispitanika $(P<0,05)$.

ZAKLJUČAK: Učestalost fibrilacije atrija, ventrikularnih ekstrasistola i supraventrikularnih ekstrasistola nije se statistički značajno razlikovala s obzirom na tip zatajivanja srca.

Ključne riječi: aritmija, zatajivanje srca, koronarna jedinica, zdravstvena skrb

Datum primitka: 13.4.2019.

Datum prihvaćanja: 1.7.2019.

DOI: $10.24141 / 1 / 5 / 2 / 10$

Adresa za dopisivanje:

Vedrana Iveta

A: Vukovarska 28, Dubrovnik, Hrvatska

E-mail: vedrana.iveta@gmail.com

T: +385915162262 


\section{Uvod}

Srčano zatajivanje jest smrtonosna i onesposobljavajuća bolest koja spada u jedan od najvećih javnozdravstvenih problema suvremene civilizacije. Zatajivanje srca skup je simptoma i znakova koji nastaju zbog nesposobnosti srca kao mišićne crpke u omogućavanju dostatne perfuzije tkiva i organa, kako bi se zadovoljile njihove metaboličke potrebe. ${ }^{1}$ Smanjenje kontraktilne funkcije srca dovodi do aktivacije kompenzatornih kardijalnih i ekstrakardijalnih mehanizama i niza hemodinamičkih, bubrežnih, neurogenih i hormonalnih poremećaja. ${ }^{2}$ Procjenjuje se da u zemljama Europske unije oko $2 \%$ odraslih boluje od zatajenja srca, dok taj broj raste nakon 65 godine na 6 do $10 \% .^{3}$ Epidemiološka istraživanja ukazuju da 30 do $40 \%$ bolesnika umire u prvoj godini od postavljanja dijagnoze, dok 60 do $70 \%$ doživi smrtni ishod unutar nekoliko godina, najčešće zbog progresije bolesti ili iznenadne aritmične smrti. ${ }^{1}$ Mortalitet u bolesnika koji su bili hospitalizirani znatno je veći od smrtnosti bolesnika oboljelih od karcinoma. ${ }^{4}$ Posljednja dva desetljeća pojavnost zatajenja srca nije se povećavala, dok je učestalost u porastu, zbog manjeg mortaliteta od srčano-žilnih bolesti. ${ }^{4}$ Ovaj je sindrom uzrok $5 \%$ svih medicinskih i gerijatrijskih hospitalizacija, posebice u starijih od 65 godina, što ukazuje na važnost preventivnog i pravodobnog liječenja. Srčana insuficijencija također je uzrok velikih troškova zdravstvenog osiguranja, u kojima čini $2 \%$ ukupnih troškova, od čega bolničko liječenje sudjeluje s oko $70 \% .^{5}$

Različiti poremećaji u strukturi, mehaničkoj funkciji ili električnoj aktivnosti srca mogu dovesti do zatajenja srca. Utvrđivanje srčanog oboljenja koje uzrokuje srčanu insuficijenciju zauzima ključno mjesto u njezinoj dijagnostici. Ishemijski, metabolički, imunološki, upalni, infektivni, endokrinološki, genetski, neoplastični procesi i trudnoća također mogu uzrokovati srčano zatajivanje. ${ }^{5}$ Uzroci su zatajivanja srca mnogobrojni, variraju ovisno o zemljopisnom području i mijenjali su se tijekom razvoja civilizacije. ${ }^{6}$

Aritmije su česta pojava u zatajivanju srca. ${ }^{7}$ Većina aritmija pojavljuje se u pacijenata s oslabljenom sistoličkom funkcijom, ali njihova pojava u pacijenata s dijastoličkim tipom zatajivanja nije rijetka. Imaju važnu ulogu jer utječu na morbiditet, mortalitet i broj hospitalizacija bolesnika. ${ }^{7}$ Primjerice, ako postoji dugotrajna fibrilacija atrija, valja imati na umu da tada postoji znatno ošte- ćenje dijastoličke funkcije, budući da nema aktivnoga doprinosa atrijske kontrakcije punjenju klijetki u teledijastoli. Ako je moguće uspostaviti postojani normalan ritam (medikamentima ili elektrokonverzijom), vrlo je vjerojatno da će normalizacija ritma predstavljati povoljnu hemodinamičku okolnost. ${ }^{8}$ Bradikardije kao posljedica oštećenja provodnoga sustava mogu dodatno pogoršati hemodinamičko stanje pa ih valja na vrijeme prepoznati i razmotriti indikaciju za ugradnju srčanoga elektrostimulatora ili ukloniti njihov mogući ijatrogeni uzrok. Bolesnici sa sindromom kroničnoga srčanog zatajenja imaju visoku smrtnost. Polovica kardiogenih smrti u kardioloških bolesnika posljedica je refraktornoga zatajivanja srca kao mišićne crpke, a druga polovica otpada na zloćudne aritmije, dakle naglu aritmogenu smrt. ${ }^{9}$ Stoga je u planiranju postupka s bolesnicima sa zatajivanjem srca važno znati pojavnost i učestalost glavnih tipova aritmija koje se mogu pojaviti tijekom bolesti.

\section{Epidemiologija srčanog zatajivanja}

Zatajivanje srca je jedan od glavnih uzroka pobola i smrtnosti u razvijenim zemljama te vodeći uzrok hospitalizacija osoba starijih od 65 godina..$^{10}$ Istraživanja pokazuju kako se povećava broj hospitalizacija osoba mlađih od 65 godina, osobito muškog spola. ${ }^{10}$ Kombinacija starenja pučanstva i poboljšanog preživljenja nakon infarkta miokarda dovela je do povećanja broja bolesnika s kroničnim zatajivanjem, a samim time i do povećanja broja hospitalizacija zbog dekompenzacije. ${ }^{7}$ Za liječenje srčanog zatajivanja u razvijenim zemljama izdvaja se oko $2 \%$ ukupnog novca namijenjenog za zdravstvo, u Sjedinjenim Američkim Državama oko 39 milijardi dolara godišnje, od čega se oko $75 \%$ odnosi na bolničko liječenje, pa je stoga riječ o važnom javnozdravstvenom problemu. ${ }^{11}$ Prema podacima studije u Framinghamu i Minnesoti te podacima Američkog udruženja za srce, pojavnost HF-PEF-a iznosi 40 do $60 \%$ među hospitaliziranima zbog zatajivanja. Prognoza je bolesnika sa zatajivanjem loša, neovisno o tipu zatajivanja. Prema podacima Framinghamske studije, do $75 \%$ muškaraca i 42 \% žena umrlo je unutar pet godina od postavljanja dijagnoze, a prema studiji iz Rochestera (provedenoj 1991.), smrtnost unutar pet godina bila je $67 \% .^{12}$ Istraživanje provedeno u Engleskoj i objavljeno 2007. godine 
pokazuje blagi napredak, ukupna smrtnost unutar pet godina iznosila je oko $40 \%$, pri tome $38 \%$ u HF-PEF-u i $47 \%$ u HF-REF-u. ${ }^{13}$.Zatajivanje srca nije zasebna bolest, nego klinički sindrom koji može imati različite uzroke. Uzroci se mogu svrstati u sljedeće kategorije: bolesti miokarda, perikarda, valvularne bolesti, endokardne bolesti, urođene i nasljedne srčane bolesti, aritmije i bolesti provođenja te stanja povezana s povećanim minutnim volumenom, kao što su hipertireoza, sepsa, anemija, beriberi ili Pagetova bolest. ${ }^{10}$

\section{Klinička slika}

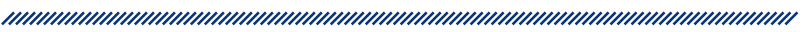

Simptomi i znaci su važni jer upozoravaju na mogućnost da postoji zatajivanje srca. Kliničku sumnju na zatajivanje srca treba potvrditi objektivnijim pretragama, osobito onima za procjenu srčane funkcije. Važni su simptomi i znaci zatajivanja srca: zaduha, oticanje gležnjeva i umor, ali ih može biti teško tumačiti, poglavito u starijih bolesnika, pretilih osoba i u žena. Treba ih pažljivo tumačiti i procijeniti različite vidove njihove pojave (npr. kod napora i noću). ${ }^{14}$ Umor je također važan simptom kod zatajivanja srca. Izvori umora su složeni i uključuju nizak srčani volumen, perifernu hipoperfuziju, lošu kondiciju skeletnih mišića, a tu su i teškoće u kvantificiranju ovoga simptoma. Periferni edem, povišeni venski tlak i hepatomegalija karakteristični su znaci kongestije sistemskih vena. ${ }^{22,}{ }^{23}$ Kliničke znakove zatajivanja srca treba procijeniti pažljivim kliničkim pregledom, uključujući opservaciju, palpaciju i auskultaciju bolesnika. ${ }^{14}$ Slaba je povezanost između simptoma i težine srčane disfunkcije. Međutim, simptomi se mogu povezati s prognozom, osobito ako ustraju nakon liječenja. Kad se postavi dijagnoza zatajivanja srca, simptomi mogu poslužiti za klasificiranje težine zatajivanja srca; koristimo ih i za praćenje terapijskih učinaka. U širokoj je primjeni klasifikacija koju je izdalo udruženje New York Heart Association (NYHA) (tablica 1). U drugim situacijama rabi se klasifikacija simptoma u blage, umjerene ili teške. Bolesnici s I. stupnjem po NYHA-i trebali bi imati objektivne dokaze srčane disfunkcije, simptome zatajivanja srca u anamnezi i primati terapiju za zatajivanje srca, kako bi se ispunila temeljna definicija zatajivanja srca. Klasifikacija koju je objavio Killip ${ }^{27}$ primjenjuje se za opis simptoma i znakova kod akutnog infarkta miokarda. Važno je prepoznati česti nesklad između simp- toma i srčane disfunkcije. Također, simptomi su slični u bolesnika s različitim razinama istisne frakcije. ${ }^{15}$ Blage simptome ne smijemo izjednačavati s manjom srčanom disfunkcijom.

\section{Tablica 1. Klasifikacija zatajivanja srca} prema funkcionalnim stadijima - NYHA

\begin{tabular}{|c|c|}
\hline I. & $\begin{array}{l}\text { Nema ograničenja: obična tjelesna aktivnost ne } \\
\text { uzrokuje pretjeran zamor, dispneju ili palpitacije }\end{array}$ \\
\hline II. & $\begin{array}{l}\text { Blaže ograničenje tjelesne aktivnosti: bez tegoba u } \\
\text { mirovanju, ali obična aktivnost dovodi do zamora, } \\
\text { palpitacija ili dispneje }\end{array}$ \\
\hline III. & $\begin{array}{c}\text { Znatno ograničenje tjelesne aktivnosti: bez tegoba } \\
\text { u mirovanju, ali već i manja od obične aktivnosti } \\
\text { dovodi do simptoma }\end{array}$ \\
\hline IV. & $\begin{array}{c}\text { Nesposobnost za obavljanje ikakve tjelesne } \\
\text { aktivnosti bez tegoba: simptomi zatajivanja srca } \\
\text { prisutni su čak i u mirovanju, uz veće tegobe kod bilo } \\
\text { kakve tjelesne aktivnosti }\end{array}$ \\
\hline
\end{tabular}

\section{Dijagnoza srčanog zatajivanja}

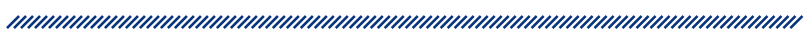

Za dijagnozu srčanog zatajivanja potrebno je, osim RTGa srca i pluća, učiniti 12-kanalni elektrokardiogram da se utvrdi srčani ritam, kao i širina QRS kompleksa (zbog prognoze, ali i indiciranja ugradnje resinkronizirajućih elektrostimulatora). Transtorakalni je ultrazvuk osnovna metoda za procjenu stanja miokarda i zalistaka. ${ }^{19} \mathrm{Ta}$ se metoda može dopuniti magnetnom rezonancijom srca koja daje bolji i detaljniji prikaz srčanih struktura i funkcije srca. Biokemijskom se analizom dobiva se uvid u oštećenje ciljnih organa (bubrega, jetre, štitnjače...), pri čemu su hiponatrijemija, kao i povišene vrijednosti kreatinina važan, iako loš, prognostički znak. Vrijednosti BNP-a, kao i NT-proBNP-a također su važni dijagnostički, ali i prognostički markeri zatajivanja srca. Koronarografija je indicirana u bolesnika u kojih se sumnja na koronarnu bolest srca, a može se dopuniti i kateterizacijom desnog srca u bolesnika u kojih se planira transplantacija srca ili implantacija potpornih uređaja. ${ }^{16}$ 


\section{Aritmije}

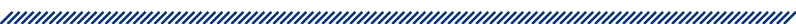

Aritmije su poremećaji koji nastaju zbog promjena u stvaranju ili provođenju impulsa u srcu. Česta su pojava u srčanom zatajivanju i mogu biti simptomatske ili asimptomatske, benigne ili maligne. Postoje tri osnovna mehanizma nastanka aritmije, bez obzira na to o kojem je tipu aritmije riječ. To su: automatizam (ubrzani ili patološki), trigerirana aktivnost i kruženje impulsa. Podloga koja omogućuje nastanak aritmija u srčanom zatajivanju jest strukturalna promjena srca, koja uključuje rastezanje miokarda, fibrozu, tvorbu ožiljaka i dilataciju srčanih odjeljaka te promjene unutarstanične i izvanstanične koncentracije iona, broja receptora i pukotinastih spojišta. ${ }^{17}$ Supraventrikularne ekstrasistole (SVES; engl. supraventricular extrasystole), ventrikularne ekstrasistole (VES; engl. ventricular extrasystole), fibrilacija atrija, paroksizmalna supraventrikularna tahikardija (PSVT; engl. paroxysmal supraventricular tachycardia), bradikardija, kratkotrajna ili produžena ventrikularna tahikardija (VT; engl. ventricular tachycardia) te ventrikularna fibrilacija (VF; engl. ventricular fibrillation) aritmije su koje se pojavljuju u zatajivanju. ${ }^{18}$ Većina aritmija pojavljuje se u bolesnika s HF-REF-om, ali njihova pojava u bolesnika s HF-PEF-om nije rijetkost. Imaju važnu ulogu, jer utječu na morbiditet, mortalitet i broj hospitalizacija. ${ }^{14} \mathrm{Klinički}$ su najvažnije fibrilacija atrija, VT i VF. ${ }^{10}$ Najgora je komplikacija aritmija iznenadna srčana smrt, koja je uzrok smrti u 30 do $50 \%$ bolesnika sa zatajivanjem II. i III. stupnja po klasifikaciji Njujorškog udruženja za srce (NYHA; engl. New York Heart Association). ${ }^{10}$

\section{Liječenje i prognoza zatajivanja srca}

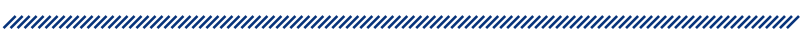

Cilj terapije bolesnika sa zatajenjem srčane funkcije jest redukcija simptoma i znakova bolesti, smanjenje broja rehospitalizacija, poboljšanje kvalitete i produživanje života. Terapijski pristup u bolesnika sa zatajenjem srčane funkcije uzrokovanim sistoličkom disfunkcijom lijeve klijetke obuhvaća općenite savjete i druge nefarmakološke mjere, farmakološku terapiju, mehanička sredstva i kirurški zahvat. Danas dostupne vrste liječenja navedene su u tablici 2.
Neodgodivo bolničko liječenje potrebno je u bolesnika sa srčanim zatajivanjem zbog određenih poremećaja (npr. akutni srčani infarkt, atrijska fibrilacija s brzim odgovorom ventrikula, teška hipertenzija, akutna insuficijencija zalistaka), kao i u bolesnika s plućnim edemom, teškim simptomima, novonastalim srčanim zatajivanjem ili srčanim zatajivanjem koje ne reagira na izvanbolničko liječenje. Bolesnici s blagim pogoršanjima ili od ranije poznatim zatajivanjem srca mogu se liječiti kod kuće. Glavni je cilj dijagnosticirati i ispraviti ili liječiti uzrok koji je doveo do zatajivanja. ${ }^{14}$ Kratkoročni su ciljevi poboljšanje simptoma i hemodinamike; izbjegavanje hipokalijemije, poremećaja funkcije bubrega i simptomatske hipotenzije te ispravljanje neurohumoralne aktivacije. Dugoročni su ciljevi regulacija hipertenzije, sprječavanje infarkta srca i ateroskleroze, smanjivanje učestalosti hospitalizacija te povećanje preživljavanja i kvalitete života. Liječenje uključuje promjene u prehrani i načinu života, lijekove, a ponekad i operaciju. ${ }^{14}$

\begin{tabular}{c} 
Tablica 2. Mogućnosti liječenja bolesnika sa \\
zatajenjem srčane funkcije \\
Nefarmakološko liječenje \\
Opći savjeti i mjere \\
Tjelesna aktivnost i vježbanje \\
Farmakološka terapija \\
ACE inhibitori \\
Diuretici \\
\hline Antagonisti beta-adrenoceptora \\
\hline Antagonisti receptora aldosterona \\
\hline Antagonisti receptora angiotenzina \\
Srčani glikozidi \\
\hline Vazodilatatori (nitrati/hidralazin) \\
\hline Pozitivni inotropni lijekovi \\
\hline Antikoagulacija \\
Antiaritmici \\
\hline Krisik \\
\hline Uređaji i kirurške metode
\end{tabular}


Liječenje treba prilagoditi bolesniku, uzimajući u obzir uzroke, simptome i odgovor na terapiju, uključujući i neželjene posljedice. Liječenje sistoličke i dijastoličke disfunkcije donekle se razlikuje, premda postoje preklapanja. Bolesnik i obitelj trebali bi biti uključeni u izbor liječenja. Trebali bi naučiti važnost suradljivosti pri uzimanju lijekova, prepoznati znakove zatajivanja srca i naučiti upotrebljavati dodatne lijekove za ublažavanje simptoma. Praćenje intenziviranog liječenja, posebno praćenje suradljivosti pri uzimanju lijekova, učestalost nedogovorenih posjeta liječniku ili odlazaka u hitnu službu te učestalost hospitalizacija može pomoći u otkrivanju kad je potrebno intervenirati. Medicinske sestre specijalizirane za zatajivanje srca važne su pri edukaciji, praćenju i prilagođivanju doza lijekova prema ranije definiranim protokolima. Mnogi centri (npr. specijalizirane nestacionarne klinike) imaju zdravstvene djelatnike različitih specijalnosti (medicinske sestre, ljekarnike, socijalne radnike, fizijatre) integrirane u multidisciplinarne timove ili programe za izvanbolničko zbrinjavanje srčanog zatajivanja. Takvi pristupi poboljšavaju ishod liječenja i smanjuju broj hospitalizacija te su najučinkovitiji u najtežih bolesnika. ${ }^{19}$

\section{Planiranje i provođenje zdravstvene njege $u$ jedinici intenzivne koronarne skrbi}

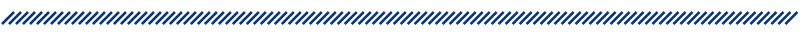

Planiranje zdravstvene njege za bolesnika u intenzivnoj koronarnoj jedinici obuhvaća utvrđivanje prioriteta, definiranje ciljeva, planiranje intervencija te izradu plana zdravstvene njege. Prikupljamo podatke metodom intervjua (socijalna vještina, planiran razgovor dviju osoba koje imaju međusobno komplementarne uloge), promatranjem (promatrati možemo od glave do pete; izgled, funkcija dijelova tijela, a počinje se od glave i nastavlja se prema nižim dijelovima tijela), promatranje velikih tjelesnih sustava (izgled i funkcija dijelova tijela koji su povezani s pojedinim sustavima) i promatranjem psihofizičkog funkcioniranja pojedinca (prikupljamo podatke o percepciji i odnosu prema zdravlju, prehrani, eliminaciji, tjelesnoj aktivnosti, spavanju $\mathrm{i}$ odmoru, kognitivno-perceptivnim funkcijama, percepciji samog sebe, uloge i odnosa s drugima, seksualnoj aktivnosti i reprodukciji, sučeljavanju i toleranciji na stres, vrijednostima i stavovima), mjerenjem i analizom dokumentacije. Sadržaj prikupljenih podataka čini sestrinsku anamnezu. ${ }^{20}$

Sestrinska je anamneza skup podataka o tjelesnim, psihološkim i socijalnim aspektima prošlog i sadašnjeg zdravstvenog stanja i ponašanja zdravog ili bolesnog pacijenta u svrhu utvrđivanja potreba za zdravstvenom njegom. Uzimanje anamneze kod koronarnog pacijenta u akutnoj fazi bolesti svodi se na nekoliko kratkih pitanja ili izostaje. Ako je pacijent vitalno ugrožen, pristupamo uzimanju heteroanamneze. Postavljamo pitanja tipa:

- Kada su nastupili simptomi?

- Koje tegobe bolesnik sada ima?

- Koje lijekove je uzeo?

- Je li alergičan na neki lijek ili kontrastno sredstvo (zbog eventualne koronarografije kod koje se primjenjuje kontrast)?

Kada je bolesnik stabilan i može surađivati uzima se kompletna anamneza. Vrlo je važno prikupiti podatke o boli; kada su počeli, što je bolesnik radio u vrijeme pojave boli te koliko je dugo bol trajala i je li se smanjila na uzimanje nitrata ili mirovanje. Prilikom uzimanja anamneze promatramo bolesnika. Vršimo fizikalni pregled koji je vrsta promatranja i uključuje inspekciju (vizualno promatranje), auskultaciju (slušno), palpaciju (taktilno) i perkusiju (slušno). Važno je uočiti i ostale simptome kao što su dispneja, tahikardija ili bradikardija, tahipnea ili bradipnea, bljedilo, mučnina, povraćanje i nemir bolesnika, kao i druge moguće simptome koji nas mogu upozoriti na razvoj komplikacija. ${ }^{21}$ Cilj je u procesu zdravstvene njege željeni, ali realan ishod zdravstvene njege. Cilj mora biti jasan i precizan opis bolesnikova stanja ili ponašanja. Dobro formulirani cilj uz opis pacijentova stanja i ponašanja, njegovu razinu, vrijeme postignuća sadrži i okolnosti u kojima će se očitovati. Kada je stanje bolesnika kritično ili kada je teško predvidjeti razvoj situacije u budućnosti, kao što je slučaj u koronarnoj jedinici intenzivne skrbi, formuliraju se kratkoročni ciljevi. Oni se postižu unutar nekoliko minuta, sati ili dana, odnose se na sadašnjost i probleme koji zahtijevaju žurno rješavanje. ${ }^{22}$ 


\section{Sestrinsko-medicinski problemi}

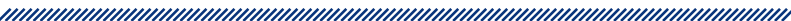

Sestrinsko-medicinski problemi su oni koji mogu proizaći iz bolesti, dijagnostičkih postupaka i načina liječenja.

Uloga je medicinske sestre:

- ciljano i savjesno promatrati bolesnikovo stanje

- pravodobno prepoznati pojavu komplikacija i uočiti pogoršanje stanja

- provoditi postupke koje propiše liječniki

- propisati i provoditi primjerene sestrinske intervencije.

Postupci sestre nisu dovoljni da se problem spriječi ili riješi, ali je važno da sestra ciljano promatra bolesnika kako bi ta stanja pravodobno prepoznala i obavijestila liječnika te kako bi sestrinskim intervencijama pridonijela cjelokupnom nastojanju uspostavljanja kontrole nad potencijalnom komplikacijom. Sestrinsko-medicinski problemi zahtijevaju sestrinske i medicinske intervencije. Primarnu odgovornost za sestrinsko-medicinske probleme imaju sestre jer one moraju uočiti. Kada se razvije određena komplikacija, postaje medicinska odgovornost. Sestre donose samostalne odluke kada tretiraju sestrinsko-medicinske probleme. ${ }^{22}$

\section{Rehabilitacija bolesnika}

Rehabilitacija bolesnika podijeljena je u tri faze:

- program u bolnici (rana rehabilitacija)

- program izvan bolnice (kod kuće, rehabilitacijski centri, medicinske ustanove)

- kontinuirani program rehabilitacije (može i ne mora biti povezan s medicinskim ustanovama).

Značaj je rehabilitacije povratak samopouzdanja, porast srčane snage $i$ obnašanja funkcije, produžetak života i poboljšanje kvalitete života. Važno je da se vježbanje obavlja dva sata nakon obroka, a ne neposredno nakon jela, u slučaju bolesti ili povišene tjelesne temperature vježbanje se odgađa, bolesnik mora biti u ugodnoj odjeći i obući, s vježbanjem se počinje polako i postupno, potrebno je izbjegavati vježbanje ako su prisutne oscilacije u temperaturi, u slučaju boli, dispneje, umora, klonulosti i gubitka daha potrebno je obavijestiti liječnika. ${ }^{23}$

Rana rehabilitacija počinje u bolnici. Fizioterapijski postupak ovisi o procjeni trenutačnog stanja bolesnika. Kontraindikacija je za fizioterapijske postupke vitalno ugrožen bolesnik, relativna je kontraindikacija prisutnost jake boli. U tom se slučaju fizioterapijski postupak odgađa do eliminiranja boli analgezijom. Bolesnik sjedi i ustaje iz kreveta uz kontrolu krvnog tlaka i srčanog ritma (monitor). Prvo ustajanje i šetnja obavljaju se uz nadzor medicinske sestre i odobrenje liječnika. Od bolesnika zahtijevamo maksimalnu aktivnu suradnju. ${ }^{23}$

Program izvan bolnice započinje po dolasku kući. Poželjno je da bolesnik postupno povećava fizičke aktivnosti. Nakon šest do osam tjedana bolesnik se upućuje u specijalizirane centre za rehabilitaciju, tzv. toplice. Tu se bolesnici osposobljavaju za normalne svakodnevne poslove $s$ iznimkom teških tjelesnih opterećenja. Kontinuirani program rehabilitacije (faza postrekonvalescencije) jest rehabilitacija u sljedećim mjesecima i godinama. $U$ ovoj fazi bolesnik je osposobljen za svoj svakodnevni posao u kući i na poslu s iznimkom teških tjelesnih opterećenja. Bolesnik mora redovito provoditi fizički trening. Važno je da bolesnik redovito dolazi na liječničke kontrole i da se kod liječnika informira o svemu što ga zanima ili što za njega predstavlja nepoznanicu.

\section{Cilj istraživanja}

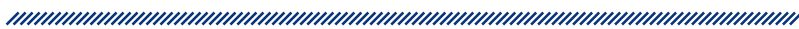

Utvrditi pojavnost i vrstu aritmija u bolesnika sa zatajivanjem srčane funkcije.

Hipoteza: Većina aritmija pojavljuje se u pacijenata sa zatajivanjem srčane funkcije sa smanjenom istisnom frakcijom. 


\section{Ispitanici i postupci}

Ovo je retrospektivna presječna studija.

Ispitanici su bili bolesnici koji su hospitalizirani u koronarnoj jedinici Opće bolnice Dubrovnik u razdoblju od 1. siječnja 2015. do 31. prosinca 2016. Podaci su prikupljeni i obrađeni na temelju uvida u povijesti bolesti i drugu dostupnu medicinsku dokumentaciju. $U$ ispitivanje su uključeni hospitalizirani bolesnici s dijagnozom srčanog zatajenja nakon postavljanja kliničkim nalazom. U istraživanje su bila uključena oba spola i nije bilo dobnih ograničenja. Iz studije su isključeni bolesnici koji su hospitalizirani zbog akutnoga koronarnog sindroma. Obrađeno je ukupno 96 ispitanika. Tijekom istraživanja ispitanici su prema vrsti srčanog zatajenja svrstani u dvije skupine: ispitanici sa zatajivanjem srca s očuvanom istisnom frakcijom i ispitanici sa zatajivanjem srca sa smanjenom istisnom frakcijom. Izlazni parametar istraživanja bio je tip srčanog zatajivanja, dok su ulazni parametri bili dob i spol bolesnika te vrsta aritmije. Prikupljeni podaci statistički su obrađeni s pomoću metoda deskriptivne statistike. Simetričnost kontinuiranih varijabli analizirana je Kolmogorov-Smirnovljevim testom. Parametrijski testovi primijenjeni su za testiranje razlike simetrično distribuiranih varijabli između istraživanih skupina, dok su nesimetrično distribuirane varijable testirane neparametrijskim testovima (Mann-Whitney U, Kruskal Walis). Za analizu kategorijskih varijabli primijenjen je $\chi^{2}$ test, dok se pri manjku očekivanih frekvencija rabio Fisherov egzaktni test. Za statističku obradbu podataka upotrijebljen je programski sustav SPSS for Windows (inačica 13.0, SPSS Inc. Chicago, Illinois, SAD) i Microsoft Excel (inačica Office 2007, Microsoft Corporation, Redmond, WA, SAD).

\section{REZULTATI}

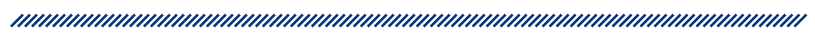

$\mathrm{U}$ istraživanju je sudjelovalo 96 ispitanika, od toga je je $45(46,8 \%)$ ispitanika i $51(53,2 \%)$ ispitanica $\left(\chi^{2}\right.$ test $=0,258 ; \mathrm{df}=1 ; P<0,611)$.

Srednja životna dob ispitanika bila je $74,5[12,0]$ (medijan [interkvartilni raspon]) godina. Najmlađi ispitanik imao je 32, a najstariji 93 godina.
Srednja životna dob muškaraca bila je $72,0[17,0]$ godina, dok je u žena iznosila 78,0 [10,0], što se primjenom Mann-Whitneyjeva testa za nezavisne uzorke pokazalo statistički značajnim ( $U=1587,50 ; Z=-3,59 ; P<0,001)$.

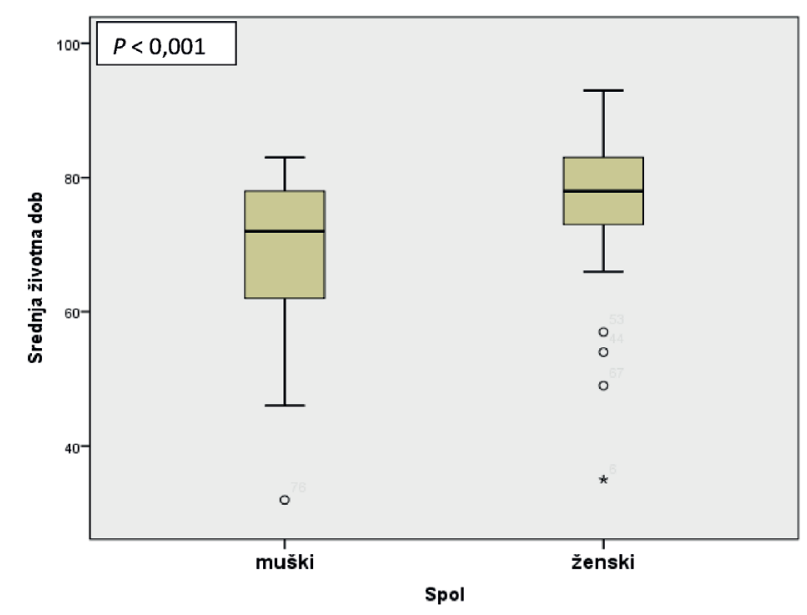

\section{Grafikon 1. Usporedba srednje životne dobi između muških i ženskih ispitanika sa zatajivanjem srčane funkcije}

Anamnestički podaci o koronarnoj bolesti srca zabilježeni su u $65(67,7 \%)$ ispitanika, arterijska hipertenzija u 45 $(46,8 \%)$, a šećerna bolest u $28(29,1 \%)$, ispitanika. Bivših ili sadašnjih pušača bilo je $16(16,6 \%)$.

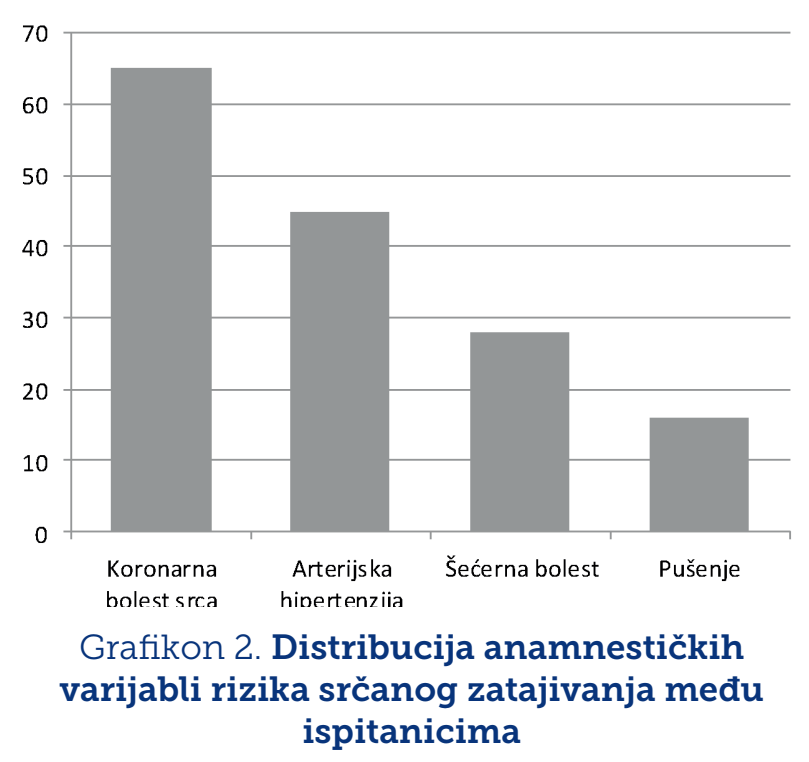

Od ukupnog broja ispitanika, u 42 (43,7 \%) slučajeva dijagnosticirano je zatajivanje srčane funkcije s očuvanom istisnom frakcijom, dok je u $54(56,3 \%)$ ispitanika dijagnosticirano zatajivanje srčane funkcije sa smanjenom istisnom frakcijom $\left(\chi^{2}=1,520 ;\right.$ d.f $\left.=1 ; P=0,220\right)$. 


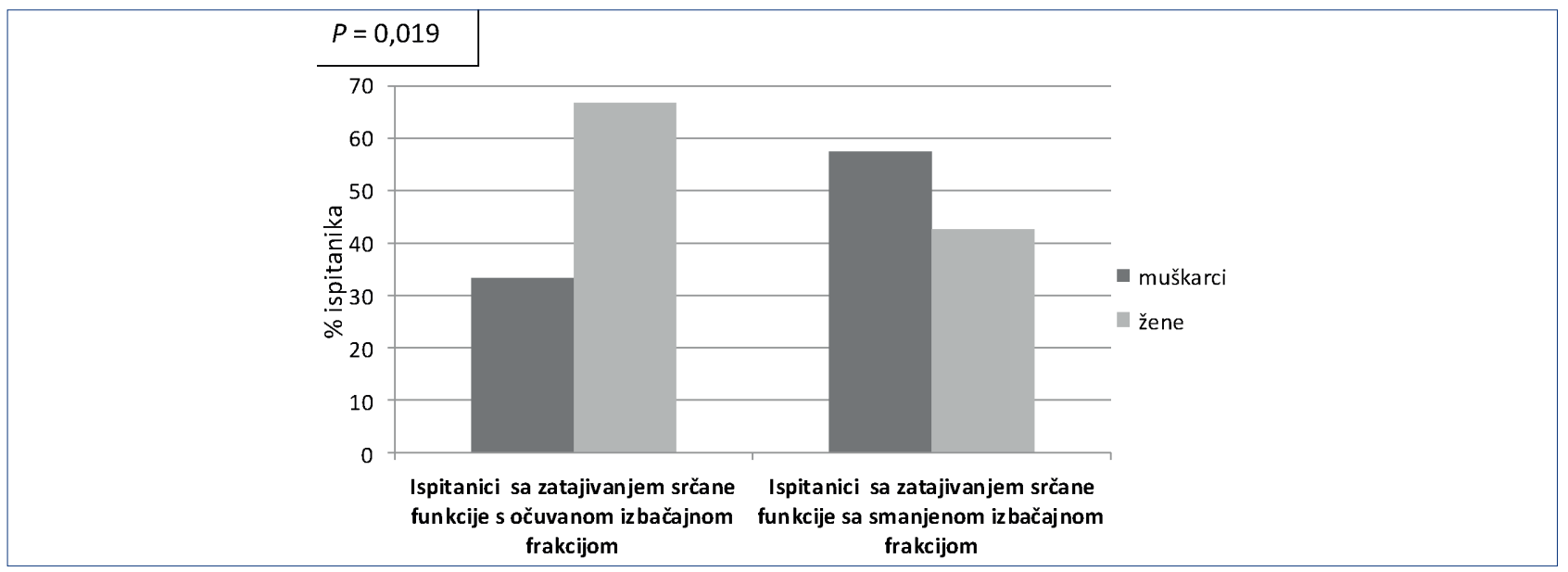

\section{Grafikon 3. Prikaz vrste zatajivanja srca prema spolu ispitanika}

Gledajući spolnu razdiobu pokazala se znatna razlika. Od ukupnog broja ispitanika sa zatajivanjem srčane funkcije s očuvanom istisnom frakcijom $(n=42)$ broj muškaraca bio je 14 (33,3\%), a žena 28 (66,7 \%), dok je u skupini ispitanika sa zatajivanjem srčane funkcije sa smanjenom istisnom frakcijom $(n=54)$ broj muškaraca iznosio 31 (57,4 \%), a žena 23 (42,5\%), što se pokazalo statistički značajnim $\left(\chi^{2}=5,498 ;\right.$ d.f $\left.=1 ; P=0,019\right)$.

Srednja životna dob ispitanika pokazala je statistički značajnu razliku u odnosu na vrstu srčanog zatajivanja. Srednja životna dob ispitanika sa zatajivanjem srčane funkcije s očuvanom istisnom frakcijom iznosila je 78,0 $[9,0]$ godina, dok je u ispitanika sa zatajivanjem srčane funkcije sa smanjenom istisnom frakcijom iznosila 72,5 $[12,0]$, što se pokazalo statistički značajnim ( $U=783,50$; $\mathrm{Z}=-2,59 ; P=0,010)$.

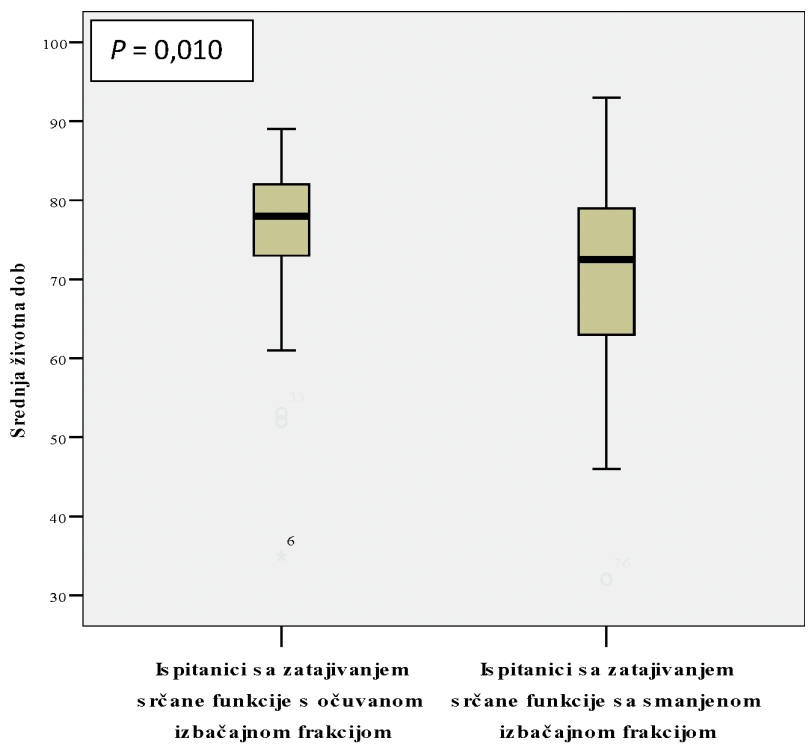

Grafikon 4. Usporedba srednje životne dobi ispitanika $u$ odnosu na tip zatajivanja srčane funkcije
Srednja vrijednost sistoličkog tlaka u ispitanika sa zatajivanjem srčane funkcije s očuvanom istisnom frakcijom iznosila je 150,0 mm/Hg [35,0], dok je u ispitanika sa zatajivanjem srčane funkcije sa smanjenom istisnom frakcijom iznosila $140,0 \mathrm{~mm} / \mathrm{Hg}[23,0]$, što se pokazalo statistički značajnim ( $U=436,0 ; Z=-2,032 ; P=0,042)$ (grafikon 5).

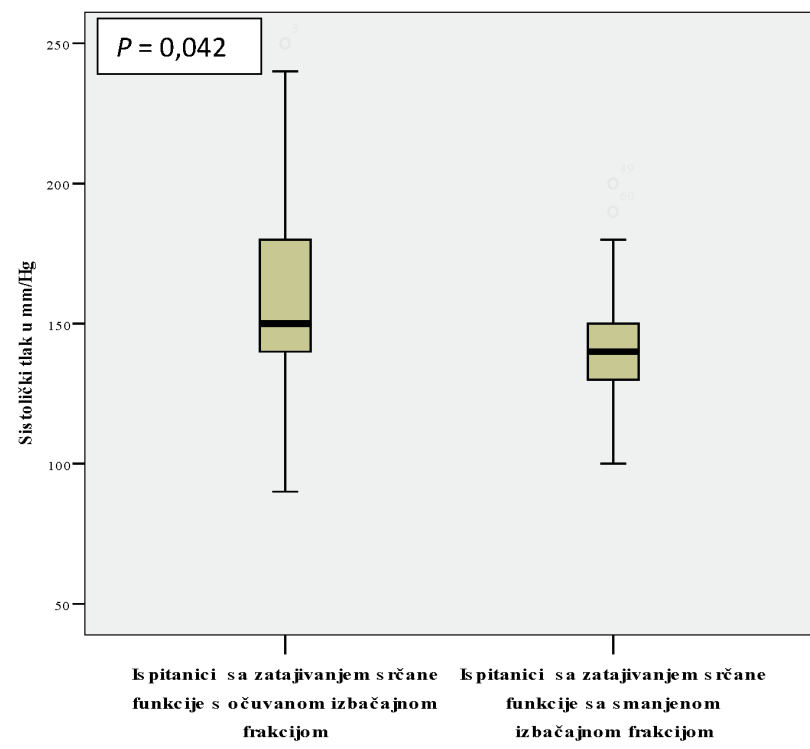

Grafikon 5. Usporedba srednje vrijednosti sistoličkog tlaka $u$ ispitanika $u$ odnosu na tip zatajivanja srčane funkcije

Srednja vrijednost dijastoličkog tlaka u ispitanika sa zatajivanjem srčane funkcije s očuvanom istisnom frakcijom iznosila je 95,0 mm/Hg [18,0], dok je u ispitanika sa zatajivanjem srčane funkcije sa smanjenom istisnom frakcijom iznosila $90,0 \mathrm{~mm} / \mathrm{Hg}[13,0]$, što se pokazalo statistički značajnim ( $U=375,0 ; Z=-2,786 ; P=0,005)$ (grafikon 6). 


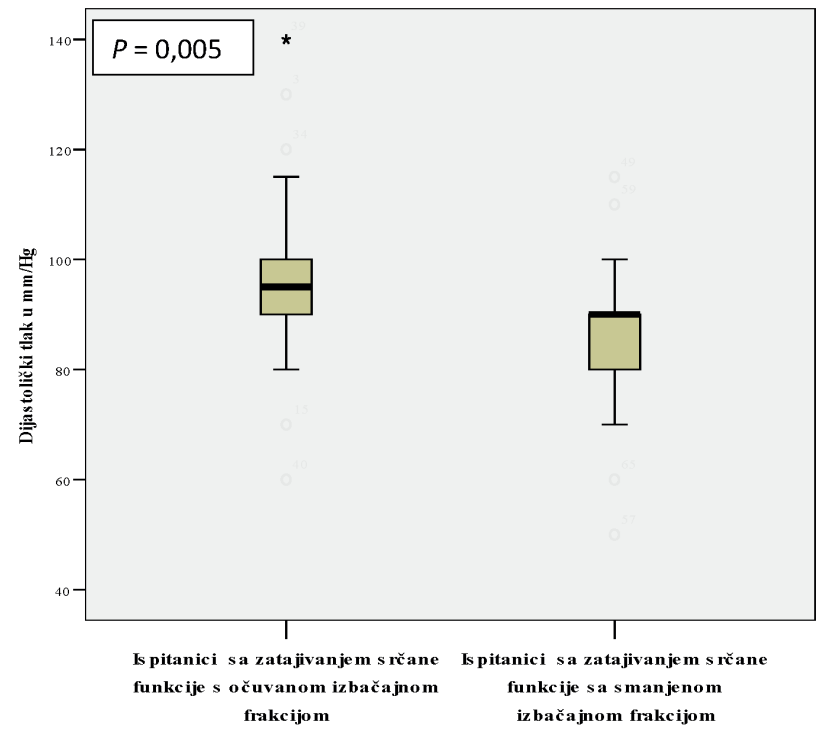

Grafikon 6. Usporedba srednje vrijednosti dijastoličkog tlaka u ispitanika u odnosu na tip zatajivanja srčane funkcije
Najučestalija vrsta aritmije $u$ ispitanika bila je fibrilacija atrija, potvrđena u $45(46,8 \%)$ ispitanika, ventrikularne ekstrasistole potvrđene su u 14 (14,5\%) ispitanika, a supraventrikularne ekstrasistole u šest $(6,2 \%)$ ispitanika $\left(\chi^{2}=39,169 ;\right.$ d.f $\left.=2 ; P<0,05\right)$.

Učestalost fibrilacije atrija, ventrikularnih ekstrasistola i supraventrikularnih ekstrasistola nije se statistički značajno razlikovala s obzirom na tip zatajivanja srca.

\section{Rasprava}

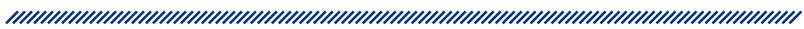

Zatajivanje srca značajan je uzrok mortaliteta i morbiditeta te je veliko medicinsko i ekonomsko opterećenje društva. Demografski čimbenici i smanjena smrtnost od koronarne bolesti srca zbog napretka u liječenju

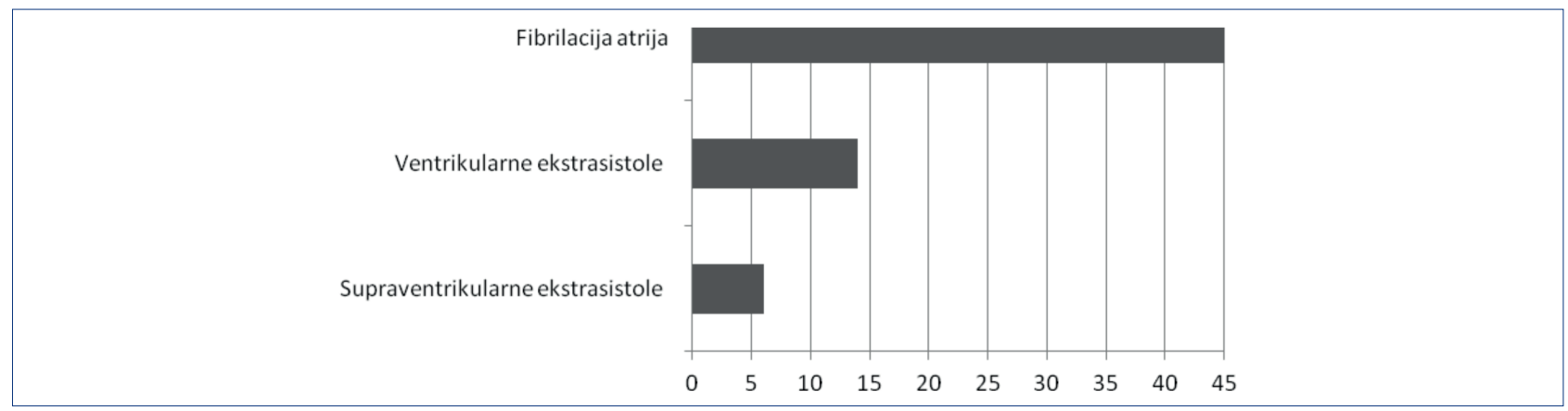

Grafikon 7. Prikaz učestalosti i vrste aritmija u bolesnika sa zatajivanjem srčane funkcije

\begin{tabular}{|c|c|c|c|c|c|c|}
\hline & \multicolumn{2}{|c|}{$\begin{array}{c}\text { Ispitanici sa } \\
\text { zatajivanjem srčane } \\
\text { funkcije s očuvanom } \\
\text { istisnom frakcijom } \\
(n=42)\end{array}$} & \multicolumn{2}{|c|}{$\begin{array}{c}\text { Ispitanici sa zatajivanjem } \\
\text { srčane funkcije sa } \\
\text { smanjenom istisnom } \\
\text { frakcijom } \\
(n=54)\end{array}$} & \multirow[t]{2}{*}{$c^{2}$ test } & \multirow[t]{2}{*}{$\mathrm{P}$} \\
\hline & $\mathrm{Br}$. & $\%$ & $\mathrm{Br}$. & $\%$ & & \\
\hline $\begin{array}{l}\text { Fibrilacija atrija } \\
\qquad \begin{array}{c}\mathrm{Da} \\
\mathrm{Ne}\end{array}\end{array}$ & $\begin{array}{l}21 \\
21\end{array}$ & $\begin{array}{l}50,0 \\
50,0\end{array}$ & $\begin{array}{l}24 \\
30\end{array}$ & $\begin{array}{l}44,4 \\
55,6\end{array}$ & 0,293 & 0,588 \\
\hline $\begin{array}{l}\text { Ventrikularna } \\
\text { ekstrasistola } \\
\mathrm{Da} \\
\mathrm{Ne}\end{array}$ & $\begin{array}{c}5 \\
37\end{array}$ & $\begin{array}{l}11,9 \\
88,1\end{array}$ & $\begin{array}{c}9 \\
45\end{array}$ & $\begin{array}{l}16,6 \\
83,4\end{array}$ & 0,430 & 0,511 \\
\hline $\begin{array}{c}\text { Supraventrikularna } \\
\text { ekstrasistola } \\
\mathrm{Da} \\
\mathrm{Ne}\end{array}$ & $\begin{array}{c}4 \\
38\end{array}$ & $\begin{array}{c}9,5 \\
90,5\end{array}$ & $\begin{array}{c}2 \\
52\end{array}$ & $\begin{array}{c}3,7 \\
96,3\end{array}$ & 1,366 & 0,553 \\
\hline
\end{tabular}


uzroci su porasta pojavnosti i učestalosti te bolesti. Visoka pojavnost i loša prognoza razlog su što se o zatajivanju govori kao o najmasovnijoj zloćudnoj bolesti današnjice. Krajem prošlog stoljeća ono je, zajedno s fibrilacijom atrija, proglašeno novonastalom epidemijom u skupini kardiovaskularnih bolesti. ${ }^{5}$ Čest je razlog hospitalizacije, posebno u osoba starije životne dobi, a remeti kvalitetu života, izaziva invalidnost i visoku smrtnost. Kliničkim pregledom bolesnika potrebno je otkriti simptome i znakove koji mogu biti manje ili više specifični, ali i utvrditi uzrok zatajivanja srca, postojanje pratećih bolesti i stanja te precipitirajućih čimbenika. Aritmije i blokovi grana, koji su česta pojava u bolesnika sa zatajivanjem, dodatno pogoršavaju kvalitetu života te povećavaju smrtnost. ${ }^{12}$

Cilj ovog istraživanja bio je utvrditi pojavnost i vrstu aritmija u bolesnika sa zatajivanjem srčane funkcije. Obrađeno je ukupno 96 bolesnika sa zatajivanjem srčane funkcije. Srednja životna dob ispitanika bila je 74,5 godina, što govori u prilog navodima iz literature da je zatajivanje srčane funkcije bolest pretežito starije životne dobi. $U$ osoba starijih od 65 godina incidencija iznosi 10 na 1000 osoba godišnje, uz visoku petogodišnju smrtnost, unatoč modernom liječenju. Učestalost zatajivanja srčane funkcije raste $s$ dobi pa se u populaciji starijoj od 75 godina kreće između 10 i $20 \% .^{5}$

Raščlambom anamnestičkih podataka ustanovi se postojanje koronarnoj bolesti srca u $68,7 \%$ bolesnika te arterijske hipertenzije u 47,3\%. To je u skladu s navodima iz literature koji navode podatak da je zatajivanje srčane funkcije najčešće udruženo s ishemijskom bolešću srca. ${ }^{5,10}$ Uzrok zatajivanja srca mogu biti i druge bolesti kao kronična opstruktivna bolest pluća, nefritisi, ciroza jetre, anemije, endokrine bolesti, autoimune bolesti i dr., no u oko $70 \%$ slučajeva uzrok su zatajivanja srca ishemija miokarda i arterijska hipertenzija. ${ }^{14}$

Istraživanje nije pokazalo postojanje razlike u pojavnosti zatajivanja srčane funkcije $s$ očuvanom istisnom frakcijom u odnosu na zatajivanje $s$ reduciranom istisnom frakcijom. Od ukupnog broja ispitanika u $44 \%$ slučajeva dijagnosticirano je zatajivanje srčane funkcije s očuvanom istisnom frakcijom, dok je u $56 \%$ ispitanika dijagnosticirano zatajivanje srčane funkcije sa smanjenom istisnom frakcijom. Senni i Redfield u svojoj studiji navode da otprilike 40 do $50 \%$ bolesnika s dijagnozom zatajivanja srca boluje od dijastoličkog zatajivanja srca s očuvanom sistoličkom funkcijom lijeve klijetke. ${ }^{25}$ Lam i suradnici u svojem su radu skupili podatke nekoliko istraživanja i zaključili da je prosječna pojavnost zatajivanja srčane funkcije s očuvanom istisnom frakcijom u tim istraživanjima $54 \%$, s rasponom pojavnosti od 40 do $71 \% .{ }^{26} \mathrm{U}$ istoj studiji navodi se kako je primijećeno da je pojavnost stalnom povećanju (s $38 \% 1987$. godine na $54 \%$ 2001. godine), ali bez poboljšanja u preživljenju, što govori da je zatajivanje srčane funkcije s očuvanom istisnom frakcijom postalo važan javnozdravstveni problem. $^{26}$

Pojavnost fibrilacije atrija u ukupnom uzorku ispitanika hospitaliziranih zbog zatajivanja iznosila je $47 \%$, što se podudara s i podacima Europskog kardiološkog društava (ESC). ${ }^{11}$ Fibrilacija atrija nakon ekstrasistolije u praksi je najčešća aritmija. ${ }^{27}$ Češća je u starijoj dobi, ali nalazi se i u mlađih osoba. Učestalost u općoj populaciji iznosi oko $0,5 \%$, u starijih od 65 godina oko $5 \%$, a iznad 75 godina gotovo $15 \% .{ }^{27}$ Osobe u dobi $>75$ godina čine $50 \%$ bolesnika s fibrilacijom atrija. Ipak, nije se pokazala razlika u pojavnosti fibrilacije atrija s obzirom na tip srčanog zatajivanja. Rezultati su dosadašnjih istraživanja o pojavnosti fibrilacije atrija s obzirom na tip zatajivanje različiti. Cleland i suradnici u svojim radovima tvrde da je fibrilacija atrija češća u bolesnika sa zatajivanjem srčane funkcije s očuvanom istisnom frakcijom. ${ }^{28}$

Ispitivana je i pojavnost ventrikularnih poremećaja ritma, koji su utvrđeni u 16,4 \% ispitanika. Studije navode veću pojavnost VES-a u odnosu na ovo istraživanje. To se može obrazložiti time što se u ovom istraživanju pojavnost aritmija procjenjivala na osnovi očitanja pojedinačnih zapisa EKG-a, a ne metodom 24-satnog monitoriranja rada srca (holter EKG) za procjenu pojavnosti ventrikularnih poremećaja ritma. Analizom rezultata također je utvrđeno da su se ispitanici razlikovali po spolu ovisno o tipu zatajivanja. Zatajivanje srčane funkcije s reduciranom istisnom frakcijom imalo je veću pojavnost u muškaraca, za razliku od zatajivanja srčane funkcije $s$ očuvanom istisnom frakcijom, gdje je češći ženski spol, što je u skladu s podacima dosadašnjih epidemioloških studija o zatajivanju. Obilježja su tog tipa zatajivanja ženski spol u 50 do $70 \%$ bolesnika te dob veća od 65 godina. ${ }^{29}$ Postojala je i razlika u dobi ispitanika ovisno o spolu. Naime, muškarci su bili znatno mlađi od žena, što potvrđuje podatak kako se povećava broj hospitalizacija mlađih muških kardioloških bolesnika. ${ }^{10}$ Budući da je nedostatak ovog istraživanja razmjerno malen broj uključenih ispitanika, svakako bi bilo potrebno provesti novo istraživanje s većim uzorkom, jer većina ispitivanih parametara nije pokazala statistički značajnu razliku između ispitivanih skupina. 


\section{Zaključak}

- bolesnici sa zatajenjem srčane funkcije osobe su visoke životne dobi. Srednja životna dob ispitanika iznosila je 74,5 godina.

- Zatajivanje srčane funkcije najčešće je udruženo $\mathrm{s}$ ishemijskom bolešću srca i arterijskom hipertenzijom.

- Nije se pokazala statistički značajna razlika između tipova zatajivanja srčane funkcije koji su ustanovljeni u ispitanika.

- Spol se pokazao statistički značajnim čimbenikom s obzirom na vrstu zatajenja srčane funkcije.Naime, žene u odnosu na muškarce statistički značajno učestalije obolijevaju od zatajivanja srčane funkcije s očuvanom istisnom frakcijom.

- Ispitanici sa zatajivanjem srčane funkcije s očuvanom istisnom frakcijom imaju statistički značajno veće srednje vrijednosti sistoličkog i dijastoličkog tlaka u odnosu na ispitanike sa zatajivanjem srčane funkcije sa smanjenom istisnom frakcijom.

- Najučestalija vrsta aritmije $u$ ispitanika bila je fibrilacija atrija.

- Učestalost aritmije nije se statistički značajno razlikovala s obzirom na tip zatajivanja srčane funkcije.

\section{Referencije}

1. Vrhovac B, Jakšić B, Reiner Z, Vucelić B. Interna medicina. Zagreb: Naklada Ljevak; 2008. str. 459-485.

2. Kelder JC, et al. The Diagnostic Value of Physical Examination and Additional Testing in Primary Care Patients With Suspected Heart Failure. Circulation 2011; 124: 2865-2873.

3. Borlaug BA, Paulus WJ. Heart failure with preserved ejection fraction: pathophysiology, diagnosis, and treatment. Eur Heart J 2011; 32: 670-679.

4. Mosterd A, Hoes AW. Clinical epidemiology of heart failure. Heart 2007; 93: 1137-1146.

5. Polić S, Glavaš D. Neke osobitosti prepoznavanja i liječenja zatajivanja srca u Republici Hrvatskoj. Radna skupina za zatajivanje srca, Hrvatsko kardiološko društvo, Hrvatska. 2011; 6(11): 286.
6. Chen J, Normand SL, Wang Y, Krumholz HM. National and regional trends in heart failure hospitalization and mortality rates for Medicare beneficiaries, 1998-2008. JAMA 2011; 306: 1669-1678.

7. Kantharia BK. Cardiac arrhythmias in congestive heart failure. Expert Rev Cardiovasc Ther. 2010; 8: 137-140.

8. Nikolić Heitzler V, Planinc D. Zatajivanje (insuficijencija) srca. U: Vrhovac B, Francetić I, Jakšić B, Labar B, Vucelić B (ur.) Interna medicina. Zagreb: Medicinska biblioteka, Naklada Ljevak, 2003: 470-482.

9. Bristow MR. Management of Heart Failure. U: Braunwald E, Zipes DB, Libby (ur.) Heart Disease, 6. izdanje. WB Saunders Company 2001: 635-658.

10. Vrhovac B, Jakšić B, Reiner Ž, Vucelić B. Interna medicina. 4. promijenjeno i dopunjeno izdanje. Zagreb: Naklada Ljevak; 2008.

11. Lloyd-Jones D, Adams RJ, Brown TM, Carnethon M, Dai S, De Simone G, i sur. Heart disease and stroke statistics--2010 update: a report from the American Heart Association. Circulation. 2010; 121: e46-e215.

12. McMurray JJ, Stewart S. Epidemiology, aetiology, and prognosis of heart failure. Heart. 2000; 83: 596-602.

13. Hobbs FD, Roalfe AK, Davis RC, Davies MK, Hare R. Prognosis of all-cause heart failure and borderline left ventricular systolic dysfunction: 5 year mortality follow-up of the Echocardiographic Heart of England Screening Study (ECHOES). Eur Heart J. 2007; 28: 1128-1134.

14. Miličić M, Polić S, Glavaš D. Radna skupina za zatajivanje srca Hrvatskog kardiološkog društva - Smjernice za dijagnostiku i liječenje kroničnoga zatajivanja srca Europskog kardiološkog društva. European Heart Journal 2005; 26(11): 1115-1140.

15. McMurray J, Ostergren J, Pfeffer M, et al. Clinical features and contemporary management of patients with low and preserved ejection fraction heart failure: baseline characteristics of patients in the Candesartan in Heart failure -Assessment of Reduction in Mortality and morbidity (CHARM) programme. Eur J Heart Fail 2003; 5: 261-270.

16. Šikić J. Kronično zatajivanje srca - terapijski pristup. Cardiol Croat. 2015; 10(1-2): 46-50.

17. Kantharia BK. Cardiac arrhythmias in congestive heart failure. Expert Rev Cardiovasc Ther. 2010; 8: 137-140.

18. Eckardt L, Haverkamp W, Breithardt G. Antiarrhythmic therapy in heart failure. Heart Fail Monit. 2002; 2: 110-119.

19. Rosdahl CB. Basic Nursing. 6. izdanje, 1995.

20. Sestrinski edukacijski magazin: Zdravstvena skrb bolesnika s kardiovaskularnim bolestima. Dostupno na: http://www.cronurse.net/novosti/hrvatskozdravstvo/

21. Ljubas Maček J. Zatajivanje srca u Hrvatskoj. Cardiol Croat. 2014; 9(11-12): 539-542.

22. Broz Lj, Budisavljević M, Franković S. Zdravstvena njega 3, Zdravstvena njega internističkih bolesnika, Školska knjiga, Zagreb, 1999.

23. Fučkar G. Uvod u sestrinske dijagnoze, Školska knjiga, Zagreb, 1996. 
24. Prlić N, Rogina V, Muk B. Zdravstvena njega 4. 1. izdanje. Školska knjiga.

25. Senni M, Redfield MM. Heart failure with preserved systolic function: A different natural history? J Am Coll Cardiol 2001; 38: 1277-1282.

26. Lam CS, Donal E, Kraigher-Krainer E, Vasan RS. Epidemiology and clinical course of heart failure with preserved ejection fraction. Eur J Heart Fail. 2011; 13: 18-28.

27. Duraković Z, Gamulin S. Zatajivanje srca. U: Gamulin S, Marušić M, Kovač Z (ur.) Patofiziologija 7. obnovljeno i izmijenjeno izdanje, Zagreb: Medicinska naklada; 2011. str. 909-921.

28. Cleland JG, Chattopadhyay S, Khand A, Houghton T, Kaye GC. Prevalence and incidence of arrhythmias and sudden death in heart failure. Heart Fail Rev. 2002; 7 : 229-242.

29. Bonow RO, Mann DL, Zipes DP, Libby P (ur.) Braunwald's Heart Disease: A Textbook of Cardiovascular Medicine. 9. izdanje. Philadelphia: Elsevier Science; 2012.

\section{Popis skraćenica}

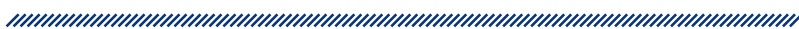

ESC - Europsko kardiološko društvo (engl. European Society of Cardiology)

FA - fibrilacija atrija

HF-PEF - srčano zatajivanje s očuvanom istisnom frakcijom (engl. heart failure with preserved ejection fraction)

HF-REF - srčano zatajivanje sa smanjenom istisnom frakcijom (engl. heart failure with reduced ejection fraction)

NYHA - Njujorško udruženja za srce (engl. New York Heart Association)

PSVT - paroksizmalna supraventrikularna tahikardija (engl. paroxysmal supraventricular tachycardia)

SVES - supraventrikularne ekstrasistole (engl. supraventricular extrasystole)

VES - ventrikularne ekstrasistole (engl. ventricular extrasystole) VF - ventrikularna fibrilacija (engl. ventricular fibrillation)

VT - ventrikularna tahikardija (engl. ventricular tachycardia) 


\section{RETROSPECTIVE ANALYSIS OF THE INCIDENCE OF ARRHYTMIA IN PATIENTS WITH HEART FAILURE AT THE CORONARY CARE UNIT OF THE GENERAL HOSPITAL DUBROVNIK}

1 Vedrana Iveta

2 Anita Miljas

3 Mara Županić

1 Health centre Dubrovnik, Dubrovnik, Hrvatska

2 General Hospital Dubrovnik, Dubrovnik, Hrvatska

3 University of Applied Health Sciences, Zagreb, Hrvatska

\section{Abstract}

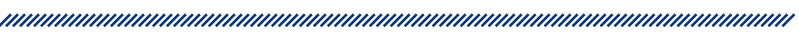

heart failure is a collection of signs and symptoms that occur due to the inability of the heart as a muscle pump in ensuring adequate perfusion of tissues and organs, in order to meet their metabolic needs. It is a deadly and debilitating disease which is one of the biggest public health problems of modern civilization.

OBJECTIVE: To determine the incidence and type of arrhythmia in patients with heart failure.

PATIENTS AND METHODS: This is a retrospective crosssectional study. The study involved hospitalized patients diagnosed with heart failure after the clinical findings in coronary care unit of the General Hospital Dubrovnik in the period from 1 January 2015 to 31 December 2016. Data was collected and analyzed on the basis of access to patient medical histories and other available medical records.
RESULTS: The study included 96 patients, of which 45 $(46.8 \%)$ men and $51(53.2 \%)$ women $(\chi 2$ test $=0.258$, $\mathrm{df}=1 ; \mathrm{P}<0.611)$. The mean age of men was $72.0[17.0]$ years, while in women it was $78.0[10.0](P<0.001)$. Of all respondents with heart failure with preserved ejection fraction (HF-PEF) the percentage of men was 33.3\% and women $66.7 \%$, while in the group of patients with heart failure with reduced ejection fraction (HF-REF), the percentage of men was $57.4 \%$, the percentage of women 42, 5\% ( $P=0.019)$. Patients with HF-PEF were significantly older than patients with HF-REF $(P<0.001)$. Patients with HF-PEF had significantly higher mean systolic $(P=0.005)$ and diastolic blood pressure $(P<0.05)$. The most common type of arrhythmia in patients was atrial fibrillation, confirmed in $46.8 \%$ of respondents $(P<0.05)$.

CONCLUSION: There is no statistically significant difference in the incidence of atrial fibrillation, supraventricular and ventricular premature beats according to the type of heart failure.

Keywords: arrhythmia, heart failure, coronary care unit, health care 